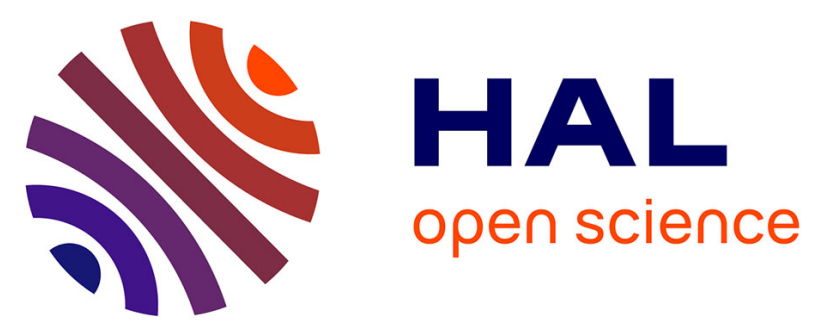

\title{
Geological evidence for fluid overpressure, hydraulic fracturing and strong heating during maturation and migration of hydrocarbons in Mesozoic rocks of the northern Neuquén Basin, Mendoza Province, Argentina
}

\author{
Alain Zanella, Peter Robert Cobbold, Gilles Ruffet, Hector A. Leanza
}

\section{To cite this version:}

Alain Zanella, Peter Robert Cobbold, Gilles Ruffet, Hector A. Leanza. Geological evidence for fluid overpressure, hydraulic fracturing and strong heating during maturation and migration of hydrocarbons in Mesozoic rocks of the northern Neuquén Basin, Mendoza Province, Argentina. Journal of South American Earth Sciences, 2015, 62, pp.229-242. 10.1016/j.jsames.2015.06.006 . insu-01165564

\section{HAL Id: insu-01165564 \\ https://hal-insu.archives-ouvertes.fr/insu-01165564}

Submitted on 19 Jun 2015

HAL is a multi-disciplinary open access archive for the deposit and dissemination of scientific research documents, whether they are published or not. The documents may come from teaching and research institutions in France or abroad, or from public or private research centers.
L'archive ouverte pluridisciplinaire HAL, est destinée au dépôt et à la diffusion de documents scientifiques de niveau recherche, publiés ou non, émanant des établissements d'enseignement et de recherche français ou étrangers, des laboratoires publics ou privés. 
Geological evidence for fluid overpressure, hydraulic fracturing and strong

heating during maturation and migration of hydrocarbons in Mesozoic rocks of the northern Neuquén Basin, Mendoza Province, Argentina Alain Zanella ${ }^{\mathrm{a}, \mathrm{b}_{*}}$, Peter R. Cobbold ${ }^{\mathrm{a}}$, Gilles Ruffet ${ }^{\mathrm{a}}$ and Hector A. Leanza ${ }^{\mathrm{c}}$

${ }^{a}$ Geosciences (UMR-6118), CNRS and Université de Rennes 1, 35042 Rennes, France

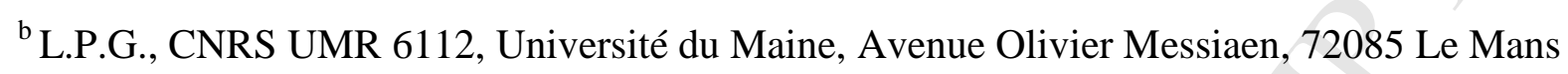

Cedex 9, France

${ }^{\mathrm{c}}$ Museo Argentino de Ciencias Naturales - CONICET, Buenos Aires, Argentina

*Corresponding author, e-mail: alain.zanella@univ-lemans.fr

\begin{abstract}
In the northern Neuquén Basin of Argentina (especially in Mendoza Province), there is strong geological evidence for fluid overpressure in the past. The evidence takes the form of bitumen veins and bedding-parallel veins of fibrous calcite ('beef'). Such veins are widespread in the fold-and-thrust belt of the Malargüe area, where bitumen mining has been active for a century or so. So as to collect information on the development of fluid overpressure in this part of the Neuquén Basin, several old mines were visited and studied in the Malargüe area. Here the bitumen veins have intruded mainly the Late Jurassic to Early Cretaceous Mendoza Group, but also the Late Cretaceous Neuquén Group. The veins have the forms of bedding-parallel sills or dykes and they are especially thick within anticlines, forming saddle-reefs in several places. Beef veins are also numerous in the Malargüe area. They contain bitumen and therefore seem to have formed at the same time as the bitumen veins. Near many outcrops of bitumen and beef, we have found fine-grained volcanic intrusive bodies. The best examples are from the La Valenciana syncline. According to ${ }^{39} \mathrm{Ar}-$ ${ }^{40} \mathrm{Ar}$ dating, these bodies are mainly of Mid-Miocene age. More generally, volcanism, deformation and maturation of source rocks seem to have reached a climax in Miocene times, when the subducting Pacific slab became relatively flat.
\end{abstract}


Keywords: Neuquén Basin, Mendoza Province, 'beef', bitumen veins, hydrocarbon migration, fluid overpressure, ${ }^{39} \mathrm{Ar}-{ }^{40} \mathrm{Ar}$

\section{Introduction}

'Beef' (bedding-parallel veins of fibrous calcite) and solid bitumen veins seem to be common in sedimentary basins worldwide. According to recent reviews (Cobbold et al. 2013; Gale et al. 2014) 'beef' or 'cone-in-cone' are common, especially within shale and/or mudstone in sedimentary basins that have generated petroleum. Asphalts and bituminous substances have been known for a long time, before 'beef' or the onset of hydrocarbon production. Abraham (1960) compiled an inventory, showing that solid bitumen veins occur in some well-known sedimentary basins, for example in Utah and Oklahoma (United States), in the State of Vera Cruz (Mexico), or in the Province of Pinar del Rio (Cuba), for North America; in the Tolima Department (Colombia), in the Province of Canta and Yauli (Peru), or in Neuquén and Mendoza provinces (Argentina), for Central and South America; and in the Province of Hanover (Germany), or the Ural Mountains (Russia), for Europe and Asia. Nevertheless, the Neuquén Basin, Western Argentina, may contain the most widespread bitumen veins in the world (Parnell \& Carey 1995), as well as being known for its high potential in oil and gas. Veins of solid bitumen (often named 'asphaltite' or less often 'neuquenite' or 'rafaelite') and of 'beef' crop out, together with source rocks for petroleum, especially in the central and northern part of the basin. There the bitumen veins have been subject to intense mining for fuel, especially during World War II. Hence the veins and mines figure in a book by Borrello (1956), as well as in many reports by the government agency, Yacimientos Carboníferos Fiscales (YCF). Recently, some of these reports became available from the Geological Survey of Argentina (SEGEMAR). According to all this information, bitumen veins are numerous in three main areas, (1) Auca Mahuida, (2) Chos Malal or Pum Mahuida and (3) the Malargüe area (Meyerhoff, 1948). These three areas are also regions where magmatic rocks are common. Indeed, several authors in the past suggested relationships between magmatic activity and the development of bitumen veins (Groeber 1923, Rassmuss 1923; Fester and Cruellas 1941, Piscione 1947, Meyerhoff 1948; Borrello 1956). In the Chos Malal area, Cobbold et al. (2011, 2014) demonstrated such relationships, by showing that vertical veins of bitumen form a radial pattern around Tromen volcano, which is of Pleistocene age, conical in shape and $4114 \mathrm{~m}$ high. 
In the Malargüe area, there is no such obvious topographic feature as Tromen volcano, but the area does contain a large amount of volcanic and magmatic rocks, mostly of Neogene or Quaternary ages (Fig. 1). Furthermore, bitumen mines are numerous and some of them are exceptionally large. Some authors have suggested that maturation and migration of petroleum in the northern Neuquén Basin could be, at least in part, due to volcanic or magmatic activity (Rodriguez et al., 2007, 2009; Witte et al. 2012). Nevertheless, there are still many questions about such a possible correlation. As a result, we decided to revisit the bitumen mines of the Malargüe area, as well as others in Mendoza province. We worked at two different scales, first by comparing as many mines as possible in the region, then by studying in detail La Valenciana Mine, which for many years was the most productive, in the area to the West of Malargüe city. As part of this work, we have used the ${ }^{39} \mathrm{Ar}-{ }^{40} \mathrm{Ar}$ method, to date magmatic rocks near the main bitumen occurrences.

\section{Geological setting}

The Neuquén Basin lies on the eastern side of the Andes (Fig. 1). The complex history of the basin began by the development of a series of Permo-Triassic grabens during a phase of continental extension, when the Choiyoi Group accumulated (Vergani et al. 1995), (Fig. 2). Then, during the Jurassic and Early Cretaceous, the basin was subject to thermal subsidence and a eustatic rise in sea level, so that marine transgressions from the Pacific Ocean led to deposition of a thick stratigraphic sequence (some $5000 \mathrm{~m}$ ), from the Remoredo Fm to the top of the Mendoza Group (Vergani et al. 1995; Franzese and Spalletti 2001; Franzese et al. 2003). In the Late Cretaceous a change in tectonic setting led to inversion of the basin and formation of a fold-and-thrust belt in the foothills of the Andes (Cobbold and Rossello 2003), (Fig. 1). At the same time, uplift and erosion provided clastic material for deposition of the Neuquén Group, further eastward (Fig. 2). The last marine deposits in the area (the Malargüe Fm of Maastrichtian to Palaeogene age) were due to transgression from the Atlantic Ocean (Legarreta and Gulisano 1989), (Fig. 2). Sedimentation then continued under continental conditions, producing synorogenic Tertiary strata (Fig. 2). In the foothills of Mendoza Province and the northernmost Neuquén Province, volcanic rocks of Tertiary or Quaternary ages are also widespread (Fig. 1). The most common ages are Miocene and their geochemical characteristics led Kay et al. (2006) to suggest that they formed during a period, when the subducting Pacific plate was flatter than normal. 
In the northern part of the Neuquén Basin, the petroleum system is simpler than it is in the central or southern parts. In Mendoza Province, the most important potential source rock is the Vaca Muerta Fm (from the Mendoza group), which consists of deep-marine organicrich black shales (Fig.2). Nevertheless, other potential source rocks can be found within the Agrio Fm or Triassic rocks. The Vaca Muerta Fm is also the main source rock for the entire Neuquén Basin (Urien and Zambrano 1994; Villar et al. 2006). In Mendoza Province, the kerogen of the Vaca Muerta Fm is intermediate between Types II and III (e.g. AlberdiGenolet et al. 2013; Askenazi et al. 2013; Legarreta \& Villar, 2012; Parnell \& Carey 1995). The TOC values are very variable for the source rock in this area, from $7.57 \%$ (area of Los Castaños) to $14.20 \%$ (area of La Valenciana). In contrast to the central part of the basin, Tmax values indicate that, in the Mendoza Province, the Vaca Muerta Fm has not surpassed the oil window (Parnell and Carey 1995).

In the Malargüe area, the foothills of the Andes have the typical structure of a foreland basin, where a series of fore-thrusts and back-thrusts affect the whole sedimentary sequence (Fig. 3). Pre-existing extensional basins (grabens and half-grabens) have been inverted, so that the Vaca Muerta source rock now crops out in the cores of anticlines (Fig. 3). According to recent work, the Malargüe fold and thrust belt formed between $15 \mathrm{Ma}$ and $1 \mathrm{Ma}$ and appears to have migrated progressively southward into the basin (Koslowski et al. 1993; Silvestro and Kraemer 2005; Giambiagi et al. 2008; Giambiagi et al. 2009).

Geological evidence for fluid overpressure, while the petroleum system was active, is widespread in the Neuquén Basin. Rodrigues et al. (2009) have already shown the importance of fluid overpressures within the Vaca Muerta source rock, but essentially in the Mulichinco area, further to the south in Neuquén Province. They concluded that maturation and generation of hydrocarbons led to fluid overpressures. They evoked load transfer and chemical compaction, during transformation of solid kerogen to oil or gas, as a possible mechanism for the development of fluid overpressure. Indeed, solid hydrocarbon veins and palaeo-hydraulic fractures are widespread, in particular within or near the Vaca Muerta source rock (Borrello 1956; Parnell and Carey 1995), (Fig. 1). Examples are bedding-parallel veins of fibrous calcite, which historically go under the name of 'beef' (Buckland and De la Beche 1835, Stoneley 1983; Cobbold et al., 2013). These fractures and the emplacement of bitumen veins, parallel to the bedding, suggest that high fluid pressure initiated and opened the fractures, which then filled with calcite and/or bitumen. For both kinds of veins, Parnell and Carey (1995) estimated the timing of formation to be Eocene-Oligocene, on the assumption that they were due to burial. 


\section{Bitumen mines}

Bitumen mines of the Malargüe area are within the fold and thrust belt, especially between latitudes $35^{\circ} \mathrm{S}$ and $36^{\circ} \mathrm{S}$ (Fig. 1 and Table. 1). The Vaca Muerta Fm is the main host rock for the mines, but some of them occur in the Neuquén Group or in the Malargüe Group (Table. 1). Within the mines, the bitumen veins are either sills or dykes. The bitumen varies in composition and maturity, from impsonite to gilsonite, but there are no obvious correlations with location or host rock (Parnell and Carey 1995), (Fig. 4). The mines are old and difficult to find, although mostly they lie close to roads or footpaths.

The following section briefly describes some of the mines, outcrops of bitumen veins and other features, such as the presence of 'beef' veins or magmatic bodies. La Valenciana Mine figures in a separate section, because of the large number of field observations, analyses and ${ }^{39} \mathrm{Ar}^{-}{ }^{40} \mathrm{Ar}$ ages.

Mercedes, Los Vascos, Minacar and Aida mines

In the southern part of the Malargüe area, four bitumen mines are visible. The first is Mercedes Mine on "Cerro Rahui" or "Monte de la Leona" mountain (n ${ }^{\circ}$ in Fig. 1 and Table 1). Nowadays, this mine is easily accessible on foot, but outcrops of old workings are poor and have almost disappeared. Nevertheless, descriptions of the mine exist in YCF reports (Biondi, 1942a, 1942b) and in the book of Borrello (1956). The mine exploited mainly one bitumen sill, 0.70 to $1.50 \mathrm{~m}$ thick, parallel to bedding, the host rock being the Mendoza Group (Lower Cretaceous). The mine lies at the top of a hill, on an anticlinal structure, which is in fact a box-fold (Fig. 5A). According to old descriptions (Biondi, 1942a), at the hinge the vein is flat-lying and as much as $4.5 \mathrm{~m}$ thick, forming a saddle-reef. The old mine entrance is still visible (Fig. 5C) and around it are many loose fragments of bitumen (Fig. 5B).

At about $2 \mathrm{~km}$ westward of Mercedes Mine, on the other side of the Rio de la Leona, lies another old mine, Los Vascos or Santa Maria (Borrello, 1956). This occurs within shale of the Mendoza Group, at the bottom of a deeply incised river valley. The old workings are still visible in part and they follow vertical veins of bitumen (up to $2.2 \mathrm{~m}$ thick), which strike approximately E-W. Possibly these veins were feeders for the sills at Mercedes Mine. At Los Vascos we also found many loose fragments of beef. These samples released strong odours of 
hydrocarbons when we broke them. They therefore contain a non-negligible quantity of volatile hydrocarbons.

The third mine in the southern area is Minacar (or General San Martin); ( ${ }^{\circ} 2$ in Fig. 1; Fig. 6A and Table 1). This mine, which was active from 1942 to 1951, followed an anticlinorium and several bitumen veins, some of which were parallel to bedding in Lower Cretaceous strata (Agrio Fm, Fig. 2), whereas others were transverse (Borrello 1956); (Fig. $6 \mathrm{~B} \& \mathrm{C})$. The main vein, which is no longer visible at outcrop, was in fact a sill or laccolith, as much as $30 \mathrm{~m}$ thick, which was just beneath gypsum-bearing evaporite of the Huitrin Fm (Lower Cretaceous, Fig. 2), or even in places reached the surface (Fester and Cruellas, 1941; Nicolas Davis, personal communication). As in Mercedes mine, so at Minacar, the bitumen was thicker at the hinge of the anticline, than on its flanks (Borrello, 1956), so that it formed a saddle-reef. At depth were a bitumen dyke, striking N-S, as well as shows of liquid oil (Fester and Cruellas, 1941). At Minacar, the bitumen is about half way in composition between impsonite and gilsonite, indicating moderate maturity (Parnell and Carey 1995, their fig. 5). Moreover, the ash that remains after burning the bitumen contains as much as $70 \%$ of vanadium pentoxide. As previously described by Parnell and Carey (1995), the bitumen has a pencillate internal structure (Fig. 6C). Near the main bitumen vein (about 50 meters from it) an andesitic body has intruded the Agrio Fm (Fig. 6D). The body is massive and it has metamorphosed the shales at its edges. The relationships between bitumen veins and magmatic activity are not very clear, but the proximity of both structures seems to be no accident, so much so that Fester and Cruellas (1941) inferred that magmatic activity was responsible for the bitumen veins.

The last visited mine in this area was Aida. This mine lies about $3 \mathrm{Km}$ southward of the town of Bardas Blancas ( $\mathrm{n}^{\circ} 3$ on the Fig. 1; Table. 1). Outcrops are not of good quality, but the remains of gallery entrances are still identifiable. The mine is on the eastern side of the Bardas Blancas anticline (Gross 1950). Bitumen occurs in the Agrio Fm, just beneath the transition with the Huitrin Fm, and it consists of veins or impregnations within shale and calcareous strata, as well as evaporites. Andesitic dykes are also present in this area (Gross 1950; Borrello 1956).

Mallín Largo, Los Castaños and El Toki mines

Between latitudes $35^{\circ} \mathrm{S}$ and $36^{\circ} \mathrm{S}$, bitumen mines were numerous in the first half of the last century. Borrello (1956) mentioned not less than 25 bitumen mines in this part of the 
Malargüe fold and thrust belt. In this section, we will describe three other mines (Mallín Largo, Los Castaños and El Toki), which illustrate bitumen occurrences.

Los Castaños and Mallín Largo mines are close to one another ( $n^{\circ} 7$ and 8 in Fig. 1; Table. 1). They lie to the south of the Rio Salado, on an anticlinal structure. Los Castaños is on the western side and Mallín Largo on the eastern side of the anticline. The bitumen veins of Los Castaños consist mainly of sills, parallel to bedding in the Vaca Muerta Fm (Borrello 1956). Outcrops are rare, but one collected sample illustrates the pencillate structure of the bitumen within a vein parallel to bedding in shale (Fig. 7A). At Los Castaños, the bitumen is relatively mature, being closer to impsonite than to gilsonite (Parnell and Carey 1995, their fig. 5). Also within shale of the Vaca Muerta Fm, around the site of Los Castaños, we found several bedding-parallel veins of fibrous calcite (beef) (Fig. 7B). The veins are typically 1 to 5 $\mathrm{cm}$ thick and contain dark patches. When we broke the beef with a hammer, we noticed strong odours of hydrocarbons.

Mallín Largo Mine lies within Neocomian strata, including the Vaca Muerta Fm. Videla Leaniz (1946) has described the mine in some detail. Bitumen forms irregular veins (up to 3 $\mathrm{m}$ thick), which dip at about $70^{\circ}$ to the NW and cut across the bedding. Only some of these veins were observed (Fig. 7C), because the mine is now only partly accessible.

El Toki was the third mine visited in this central part of the Malargüe area ( $n^{\circ} 6$ on Fig. 1; Table. 1). Here bitumen veins cut through the Neuquén Group (Late Cretaceous) and Tertiary strata (Borrello 1942a, 1956). Veins are typically 0.50 to $1.50 \mathrm{~m}$ thick, but one of them is $40 \mathrm{~cm}$ thick, within Tertiary conglomerate (Fig. 7D). Nearby is an oblique vein, which follows an eastward-verging thrust fault. Westward, some thin bitumen veins occur (less than $1 \mathrm{~cm}$ thick), lining a right-lateral flower structure, which has flat-lying strike-slip striations, trending at $035^{\circ}$. Thus in this area there is evidence for bitumen generation during Tertiary transpressional tectonics.

\section{Eloisa and General Mitre mines}

In the northern Malargüe area, two mines caught our attention, Eloisa and General Mitre. Eloisa lies at an altitude of $3100 \mathrm{~m}$, at the northern head of a valley (about $7 \mathrm{~km}$ long) and it is accessible on foot or on horseback ( $n^{\circ} 11$ on Fig. 1; Table. 1). Salas (1892) identified bitumen in this area. Today the mine workings have almost disappeared, but we found some good outcrops (Fig. 8A). Borrello (1942b, 1956) has provided a detailed description of the area. The sedimentary sequence is Mid-Jurassic to Mid-Cretaceous in age. However, it has 
been overturned above an eastward-verging thrust fault and now dips gently westward. In the East, mine workings follow bitumen dykes (trending about $075^{\circ}$ ), which have intruded continental sandstones of the Neuquén Group, beneath clays and evaporites of the stratigraphically older Huitrín Fm (Fig. 8A). Further W, bitumen sills (up to 2 m thick) lie parallel to bedding within the Huitrín evaporites (Borrello, 1956, figure 92). Above them, the Mendoza Group contains an andesite sill, and small dykes of bitumen crosscutting it. Similar dykelets of bitumen also crosscut the Vaca Muerta Fm. Finally, to the E of Eloisa Mine, Tertiary volcanic rocks (andesites) unconformably overlie the sedimentary sequence. We did not find bitumen within them.

General Mitre ( ${ }^{\circ} 10$ on the Fig. 1; Table. 1$)$ is an easily accessible mine, lying as it does near a farmhouse, along a provincial road. Again, Salas (1892) was the discoverer. Bitumen there forms several dykes, $50-60 \mathrm{~cm}$ thick, which strike at about $70^{\circ} \mathrm{N}$, cutting through the Late Cretaceous Neuquén Group (Fig. 8B), (Borrello 1956). At Mitre mine, the bitumen is the least mature, being closer in composition to gilsonite, than to impsonite (Parnell and Carey 1995, their fig. 5). Structurally the mine is to the $S$ of a thrust fault (Fig. 1).

\section{La Valenciana Mine}

The discovery of La Valenciana ( ${ }^{\circ} 5$ in Fig. 1; Table. 1) dates back to 1922. It soon became the biggest bitumen mine of the Malargüe fold and thrust belt (Ljungner 1931) and therefore deserves special attention. For this mine (and the adjacent exploration sites of La Porteña, La Cordobesa, York, Invisible, La Poderosa, La Francesa and La Malargüina) there have been many descriptions of bitumen occurrences (e.g. Ljungner 1931; Meyerhoff 1948; Borrello 1956; Parnell and Carey, 1995). The main mine entrance was on the SE flank of the La Valenciana syncline, which trends approximately NE-SW (Fig. 10). The main occurrence of bitumen was in the form of a sill, as much as $4 \mathrm{~m}$ thick and 150-200 $\mathrm{m}$ long. This is no longer visible, although one of us (PRC) did see it in May 2000. The old mine workings have collapsed in recent years, but photographs and mine plans remain (Ljungner 1931; Meyerhof 1948; Borrello 1956). By comparison with Mercedes and Minacar, the bitumen at La Valenciana has a composition that is much closer to impsonite than to gilsonite (Parnell and Carey 1975, their fig. 5), indicating a relatively high maturity for the bitumen.

Around La Valenciana mine, bedding-parallel veins of fibrous calcite (beef) are also widespread within the Vaca Muerta source rock, which occupies the core of the syncline 
(Parnell and Carey 1995). The calcite fibres are in general perpendicular to the walls of the veins (Figs. 11A \& 11D), but in some examples they curve sigmoidally towards the edges, indicating deformation during growth (Figs. 11B \& 11D). Cone-in-cone structures, consisting of shale fragments, occur near the centres of some beef veins (Fig. 11D). This beef also contains patches of bitumen (Figs. 11D \& 11E), which follow an irregular surface, approximately parallel to the edges of the vein and where the calcite fibres start to curve (Fig. $11 \mathrm{E})$. This would indicate that bitumen was forming at the onset of deformation. The distribution of beef veins is not homogeneous throughout the Vaca Muerta Formation. The beef is more common around bitumen intrusions and also close to igneous intrusive bodies. Thus, beef veins are very heterogeneous vertically and horizontally within the Vaca Muerta Formation. Near some of these, the beef appears to be less fibrous, indicating that it has recrystallized, at least in part (compare Figs. 11A \& 11B). It is particularly visible to the West of the La Valenciana Syncline, where the Vaca Muerta Formation became very close to the igneous pluton of Cerro Puchenque. Each sample of beef veins, when broken in the field, had a strong odour of hydrocarbons. Near volcanic intrusions, travertine is very common (Fig. 11C). It also smells of hydrocarbons when broken and attests to fluid circulation around igneous rocks at not very deep burial.

In the central and southern parts of the La Valenciana syncline, large amounts of igneous rocks have intruded Mesozoic strata of the Mendoza Group (Figs. 10 \& 12). Most of the intrusive bodies are dykes, but some of them are wide-ranging bedding-parallel sills. The dykes are of andesitic composition and typically 2 to $15 \mathrm{~m}$ thick (Fig. 12C). They have an average strike of $100-110^{\circ} \mathrm{N}$ and cut though the entire syncline. This orientation for dykes is consistent with the shortening direction during late Oligocene to Early Miocene ages. In detail, however, the dykes appear to form a somewhat radial pattern, as if they emanated from a large intrusive pluton, the Cerro Puchenque (Fig. 10). In general, the sills are somewhat thinner ( 1 to $10 \mathrm{~m}$ thick).

In contrast, in the northern part of the La Valenciana syncline, intrusive rocks are not of andesitic composition, but dacitic (Fig. 12D). Structurally, these dacitic intrusive rocks (sills and dykes) seem to cut the andesitic bodies, but the relationships are not clear everywhere. At its NE end, the main bitumen sill seems to terminate against a major andesitic dyke (Fig. 10; see also Meyerhoff 1948, his fig. 3). Nevertheless, we have seen no evidence allowing us to determine the relative timing of the bitumen sill and the andesitic dyke. However, in the YCF report by Ljungner (1931) an interpretative cross-section of the La Valcenciana Syncline shows that the volcanic activity post-dates the main bitumen intrusion. 
Other occurrences of bitumen lie around the La Valenciana Syncline. La Malarguina, which crops out at about $5 \mathrm{~km} \mathrm{SW}$ of La Valenciana, is one of these other small mines (Table 1, Fig. 1). According to Borrello (1956), bitumen veins of high thermal grade, 2 to $5 \mathrm{~cm}$ thick, were visible there, at the edges of a dyke and sill of Tertiary andesite. Similarly, at another locality (La Francesa), some $2.5 \mathrm{~km}$ NNE of La Valenciana, small bitumen veins (up to $2 \mathrm{~cm}$ thick) occupied joints within a large sill of andesite. Thus the evidence in this region is for bitumen generation during volcanic activity.

\section{Volcanic rocks}

In the Malargüe fold and thrust belt, volcanic rocks are abundant (Fig. 1). Most of them are of Tertiary or Quaternary ages. Geologically, bitumen mines lie in general near local volcanic provinces. This is so for the mines (previously described) Minacar, Aida, El Toki, Los Castaños and Eloisa, but also for La Valenciana Mine, described in the previous section. On the basis of these observations, volcanic rocks have been investigated more intensively. Because the bitumen mines are old and degraded, no direct structural relationships between bitumen veins and igneous rocks have been observed. However, they were sampled for ${ }^{39} \mathrm{Ar}-$ ${ }^{40}$ Ar dating (Table 2, Fig. 9). These volcanic rocks are mainly of andesitic composition, but some of them are of dacitic composition. This is particularly clear in the northern part of the La Valenciana syncline (Fig. 10, 11C \& 11D). In detail, ${ }^{39} \mathrm{Ar}-{ }^{40} \mathrm{Ar}$ age spectra have been obtained for 42 samples of whole rock or phenocrysts, from 7 localities (Figs. 9 \& 13; Table 2). Nonetheless, some samples did not provide any plateau ages. That is why Table 2 shows only 38 analyses.

Except for the La Valenciana samples, the results fall into two main groups. The first group is of Miocene age and ranges from 10.3 to 14.2 Ma. The second group is of Quaternary age, from 0.75 Ma to 0.20 Ma (Fig. 9). Only one area, near Eloisa Mine and the Rio Diamante, yielded different ages, between 3.6 Ma and 6.2 Ma (Fig. 9).

The samples from the La Valenciana Syncline are of andesitic or dacitic intrusive rocks, and also of ignimbrites, which lie mostly in the valleys of the La Valenciana Syncline. Of 20 samples from the La Valenciana area, 18 have yielded Miocene ages (14.6 to 9.4 Ma, Langhian to Tortonian, Fig. 13). This corroborates the stratigraphic chart and geological map (at a scale of 1:250,000) for the Malarguie area (Nullo et al. 2005), which have these volcanic 
rocks (“Ciclo Eruptivo Huincán”) as "Lower to Upper Miocene” in age (14 to $5 \mathrm{Ma}$ ). In detail, andesitic intrusive rocks yield ages from 9.9 to $14.6 \mathrm{Ma}$, whereas dacitic rocks display slightly younger ages, from 9.4 to $9.9 \mathrm{Ma}$ (Table. 2, Fig. 13). In contrast, the two very recent ages (0.18 and 0.17 Ma, Fig. 13) correspond to Quaternary ignimbrites.

\section{Discussion}

Evidence for hydrocarbon migration is abundant in the Malargüe fold and thrust belt. Most obvious at the surface are the bitumen mines and veins. Nevertheless, the timing of generation of the bitumen is still uncertain. From the burial history and assuming a standard thermal gradient $\left(30^{\circ} \mathrm{C} / \mathrm{km}\right)$, Parnell and Carey (1995) suggested that oil and therefore bitumen veins formed in the Eocene to Oligocene. Furthermore, other authors inferred that the maturity of the Vaca Muerta Fm increased progressively, from Upper Cretaceous to Miocene times (Legaretta et al. 2005; Rodriguez et al. 2009). However, some of our data are inconsistent with this timing. Furthermore, Kay et al. (2006) have shown that magmatic activity in the northern Neuquén Basin reached a peak in the Miocene, as confirmed by ${ }^{39} \mathrm{Ar}-$ ${ }^{40} \mathrm{Ar}$ data from this study, at a time when the subducting slab at the Pacific margin became relatively flat.

All occurrences of bitumen and beef veins are the results of fluid overpressure, which led to natural hydraulic fracturing of the rock (e.g. Rodrigues et al. 2009). This phenomenon is very common in sedimentary basins and generates either sills or dykes, depending on the tectonic context of the basin, as previously illustrated by physical modelling (Zanella et al. 2014). Bitumen sills of the Malargüe area tend to occur within anticlines as saddle-reefs, a good example being Mercedes Mine. This is evidence that hydrocarbons were migrating during a phase of compressional tectonics, when $\sigma_{\mathrm{v}}$ was the minimum stress. Even if this condition is not necessary to develop horizontal hydraulic fractures, it indicates that sills are easier to generate than dykes within an anisotropic and impermeable source rock (for example, the Vaca Muerta Formation). Furthermore, the bitumen tends to have a pencillate internal structure, which suggests progressive opening of veins, as a result of high fluid pressure (Parnell and Carey 1995). Further evidence for overpressure is the presence of beef veins along the fold and thrust belt. These bedding-parallel veins of fibrous calcite also indicate progressive opening, as a result of high fluid overpressure within the enclosing strata, which commonly are source rocks for petroleum (Rodrigues et al. 2009; Cobbold et al. 2013). 
At La Valenciana, curving calcite fibres provide evidence for ongoing deformation, during opening of the veins. Possibly this was another result of compressional tectonics.

Like previous authors, we have observed that bitumen veins in the Neuquén Basin tend to occur near volcanic intrusive bodies, good examples being at La Valenciana and Minacar mines. In fact, the Malargüe area is not the only example of coexisting bitumen, beef and volcanic intrusive rocks in the Neuquén Basin. A particularly good example is in Neuquén Province, around the Tromen Volcano (Cobbold et al. 2014). Indeed, volcanism could provide much of the heat that is necessary for maturation of source rock and especially for the formation of high-grade pyrobitumen (Abraham 1960).

Kay et al. (2006) concluded that volcanic activity for the northern part of the Neuquén Basin reached a peak during the Miocene. Furthermore, they attributed volcanic activity and compressional tectonics to flattening of the subducting Pacific slab during the Miocene. Our ${ }^{39} \mathrm{Ar}-{ }^{40} \mathrm{Ar}$ analyses are consistent with this timing and allow a more detailed geochronological interpretation for this part of the basin. Indeed, two distinct peaks of intense volcanic activity are visible in the northern part of the Neuquén Basin (Fig. 14). At a regional scale these two volcanic activities range firstly from 11.9 to $14.9 \mathrm{Ma}$ and secondly from 9.2 to $11.2 \mathrm{Ma}$ (Fig. 14A). At a local scale, in the La Valenciana Syncline area, these ranges are still clearly identified and even reflect an acidification of the magma, contemporary with a northward migration of the intrusions (Figs. $10 \& 14 \mathrm{~B}$ ).

In the Malargüe area, the overpressure, which led to hydraulic fracturing and the formation of bitumen and beef veins within Vaca Muerta source rock, can be explained by a mechanism of chemical compaction and load transfer (see Swarbrick et al., 2002). Due to strong volcanic activity during the Miocene, the Vaca Muerta Formation probably underwent greater maturation than by burial alone. This probably led to the generation of hydraulic fractures filled by bitumen and calcite (beef). It could be consistent with the study of AlberdiGenolet et al. (2013), who demonstrated a link between Tertiary volcanic activity and a pulse of hydrocarbon generation. However, we would admit that the presence of evaporite layers might have enhanced the overpressure and retained the hydrocarbons within the source rock. From what we have seen so far, we would infer that volcanic activity, compressional tectonics and bitumen generation are probably all of Miocene age in the Malargüe fold-and-thrust belt.

\section{Conclusions}


In the northern part of the Neuquén Basin, bitumen veins and bedding-parallel veins of fibrous calcite (beef) are widespread, especially within strata of the Mendoza Group, including the Vaca Muerta source rock. In the Malargüe fold and thrust belt, old bitumen mines form outcrops, which are worth visiting for the study of fluid generation and migration within source rock. Bitumen veins and calcite beef veins are consequences of hydrocarbon generation, which led to fluid overpressure and hydraulic fracturing. The hydraulic fracturing of the sedimentary sequence and mostly of the Vaca Muerta Formation was the consequence of several synchronous processes: volcanic activity, compressional tectonics and hydrocarbon generation. New ${ }^{39} \mathrm{Ar}-{ }^{40} \mathrm{Ar}$ dating in the Malargüe fold and thrust belt, especially in the La Valenciana Syncline, has confirmed Miocene ages (Langhian to Tortonian) for volcanic rocks, which lie near bitumen veins. Therefore, like most previous authors, we consider that these bitumen veins formed in the Early to Middle Miocene. In contrast, hydrocarbon generation could have started during earlier burial.

Considering the complexity of this part of the Neuquén Basin, we infer, like previous authors (e.g. Kay et al., 2006), that flattening of the subducting Pacific slab could have induced synchronicity between several geological events, such as an increase in volcanic activity, as well as compressional tectonics and hydrocarbon generation.

\section{Acknowledgements}

We are grateful to Statoil, for funding the PhD research project of Alain Zanella. Tony Boassen of the Statoil Research Centre in Trondheim was instrumental in obtaining images of beef under the scanning electron microscope (ESEM). We thank the SEGEMAR for making available to us copies of hitherto unpublished reports by Yacimientos Carboníferos Fiscales. Christian Le Carlier de Veslud helped in the construction of Fig. 10. Juan Spacapan (Universidad Nacional de La Plata) provided very useful assistance in field mapping, especially around La Valenciana Mine. Nicolas Davies was kind enough to provide unpublished information, from the time when he worked on some of the bitumen mines.

\section{References}

Abraham, H., 1960. Asphalt and allied substances. Volume 1, Sixth Edition, D. Van Nostrand Company, New York, U.S.A., 325 pages. 
Alberdi-Genolet, M., Cavallaro, A., Hernandez, N., Crosta, D. E., Martinez, L., 2013.

Magmatic events and sour crude oils in the Malargüe area of the Neuquén Basin, Argentina. Marine and Petroleum Geology, 43, 48-62.

Askenazi, A., Biscayart, P., Cáneva, M., Montenegro, S., Moreno, M., 2013. Analogía entre la Formación Vaca Muerta y Shale Gas/Oil Plays de EEUU. Argentine Section, Young Professionals Committee, Society of Petroleum Engineers.

Biondi, J.L., 1942a. Informe preliminar de la zona de Mina Mercedes, Provincia de Mendoza. Yacimientos Carboníferos Fiscales, Informe, 97, 1-6.

Biondi, J.L., 1942b. Informe de la Comisión Carbón Mineral № 52, correspondiente al mes de abril de 1942. Yacimientos Carboníferos Fiscales, Informe (unpublished report).

Borrello, A.V., 1942a. El yacimiento de asfaltita “El Toki”, Mendoza. Yacimientos Carboníferos Fiscales, Informe, 65, 1-4 (unpublished report).

Borrello, A.V., 1942b. Informe sobre la mina "Eloisa" (San Rafael) Provincia de Mendoza. Yacimientos Carboníferos Fiscales, Informe, 91, 1-7.

Borrello, A.V., 1956. Recursos minerales de la República Argentina. III. Combustibles sólidos minerales. Revista del Instituto Nationales de Investigación de la Ciencias Naturales y Museo Argentino de Ciencias Naturales "Bernardino Rivadavia”, Ciencias Geológicas, 5, 1-665.

Buckland, W., De la Beche, H.T., 1835. On the geology of the neighbourhood of Weymouth and the adjacent parts of the coast of Dorset. Transactions of the Geological Society, London, s2-4, 1-46.

Cobbold, P.R., Rossello, E.A., 2003. Aptian to recent compressional deformation, foothills of the Neuquén Basin, Argentina. Marine and Petroleum Geology, 20, 429-443.

Cobbold, P.R., Ruffet, G., Leith, L., Løseth, H., Rodrigues, N., Galland, O., Leanza, H.A., 2011. Combustibles sólidos (asfaltita). In: XVIII Congreso Geológico Argentino, Neuquén, Relatorio, Capítulo 58, pp. 689-695.

Cobbold, P.R., Zanella, A., Rodrigues, N., Løseth, H., 2013. Bedding-parallel fibrous veins (beef and cone-in-cone): worldwide occurrence and possible significance in terms of fluid overpressure, hydrocarbon generation and mineralization. Marine and Petroleum Geology, 43, 1-20, doi: 10.1016/j.marpetgeo.2013.01.010.

Cobbold, P.R., Ruffet, G., Leith, L., Loseth, H., Rodrigues, N., Leanza, H.A., Zanella, A., 2014. Radial patterns of bitumen dykes around Quaternary volcanoes, provinces of northern Neuquén and southernmost Mendoza, Argentina. Journal of South American Earth Sciences, 56, 454-467. 
Fester, G.A., Cruellas, J., 1941. Yacimientos de asfaltitas de carácter especial. Revista de Minería y Geología Minera, 12 (1,2), 31-37.

Gale, J.F., Laubach, S.E., Olson, J.E., Eichhubl, P., Fall, A., 2014. Natural fractures in shale: A review and new observations. AAPG Bulletin, 98(11), 2165-2216.

Giambiagi, L., Bechis, F., García, V., Clark, A.H., 2008. Temporal and spatial relationships of thick- and thin-skinned deformation: A case study from the Malargüe fold-and-thrust belt, southern Central Andes. Tectonophysics, 459, 123-139, doi:10.1016/j.tecto.2007.11.069.

Giambiagi, L., Ghiglione, M., Cristallini, E., Botesi, G., 2009. Kinematic models of basement-cover interaction: Insights from the Malargüe fold and thrust belt, Mendoza, Argentina. Journal of Structural Geology, 31, 1443-1457, doi:10.1016/j.jsg.2009.10.006

Groeber, P., 1923. Origen del petróleo de Barrancas. Deducciones que sugiere su estudio. Boletín de la Dirección General de Minas, Geología e Hidrología, Serie F (Informes Preliminares y Communicaciones), 6 (1), 3-14.

Gross, W.G., 1950. Examen geológico-minero de mina Aída, Llano Blanco - Mendoza. Yacimientos Carboníferos Fiscales, Informe, 714, 1-6 (unpublished).

Jacob, H., 1989. Classification, structure, genesis and practical importance of natural solid oil bitumen ("migrabitumen"). International Journal of Coal Geology, 11, 65-79

Kay, S.M., Burns, W.M ., Copeland, P., Mancilla, O., 2006. Upper Cretaceous to Holocene magmatism and evidence for transient Miocene shallowing of the Andean subduction zone under the northern Neuquen Basin. In: Kay, S.M., Ramos, V.A. (eds), Evolution of an Andean Margin: A tectonic and magmatic view from the Andes to the Neuquén Basin $\left(35^{\circ}-39^{\circ} \mathrm{S}\right.$ lat), Geological Society of America, Special Paper, 407, 19-60.

Kozlowski, E.E., Manceda R., Ramos, V.A., 1993. Estructura: XII Congreso Geológico Argentino, Geología y Recursos Naturales de Mendoza, Relatorio 1, 235-256.

Legarreta, L., Gulisano, C.A., 1989. Análisis estratigráfico de la cuenca Neuquina (Triásico superior-Terciario inferior). In: Chebli, G.A. \& Spalletti, L.A. (eds), Cuencas Sedimentarias Argentinas. Universidad Nacional de Tucumán, Serie de Correlación Geológica, 6, 221-244.

Legarreta, L. \& Villar, H. J., 2012. Las facies generadoras de hidrocarburos de la Cuenca Neuquina. Petrotecnia, agosto 2012, 14-39.

Ljungner, E., 1931. El carbón asfáltico de Las Romanas (Mina La Valenciana) en el Distrito de Malargüe (Departamento de San Rafael). Dirección General de Minas, Geología e Hidrología, Informe, 1-11 (unpublished report). 
Meyerhoff, H.A., 1948. The occurrence and mining of solid bitumens in western Argentina.

Transactions of the American Institute of Mining Engineers, 181, 403-412.

Nullo, F.E., Stephens, G., Combina, A., Dimieri, L., Baldauf, P., Bouza, P., 2005. Hoja geológica 3569-III/3572-IV, Malargüe, Provincia de Mendoza. Programa Nacional de Cartas Geológicas de la República Argentina, 1:250.000, Servicio Geológico Minero Argentino, Instituto de Geología y Recursos Minerales, Boletín, 346, 1-85.

Parnell, J., Carey, P.F., 1995. Emplacement of bitumen (asphaltite) veins in the Neuquén Basin, Argentina. American Association of Petroleum Geologist Bulletin 79, 1798-1816. Piscione, C.A.S., 1947. Asfaltitas y pirobitumen asfáltico. Revista de la Sociedad Geológica Argentina, 2, 65-87.

Rassmuss, J., 1923. Breves apuntes geológicos sobre la parte del territorio del Neuquén entre Auca Mahuida y El Tromen. Dirección General de Minas, Geológia e Hidrogeología, Serie F (Informes Preliminares y Communicaciones), 6 (1), 15-20.

Renne, P.R., Swisher, C.C., Deino, A.L., Karner, D.B., Owens, T.L., De Paolo, D.J., 1998. Intercalibration of standards, absolute ages and uncertainties in ${ }^{40} \mathrm{Ar} /{ }^{39} \mathrm{Ar}$ dating. Chemical Geology, 145, 117-152.

Renne, P.R., Mundil R., Balco G., Min K., Ludwig R.L., 2010. Joint determination of ${ }^{40} \mathrm{~K}$ decay constants and ${ }^{40} \mathrm{Ar} \square /{ }^{40} \mathrm{~K}$ for the Fish Canyon sanidine standard, and improved accuracy for ${ }^{40} \mathrm{Ar} /{ }^{39} \mathrm{Ar}$ geochronology. Geochimica Cosmochimica Acta, 74, 5349-5367. Renne, P.R., Balco G., Ludwig R.L., Mundil R., Min K., 2011. Response to the comment by W.H. Schwarz et al. on "Joint determination of ${ }^{40} \mathrm{~K}$ decay constants and ${ }^{40} \mathrm{Ar} \square /{ }^{40} \mathrm{~K}$ for the Fish Canyon sanidine standard, and improved accuracy for ${ }^{40} \mathrm{Ar} /{ }^{39} \mathrm{Ar}$ geochronology" by PR Renne et al. (2010). Geochimica Cosmochimica Acta, 75, 5097-5100.

Rodrigues, N., Cobbold, P.R., Løseth, H., Ruffet, G., 2009. Widespread bedding-parallel veins of fibrous calcite ("beef”) in a mature source rock (Vaca Muerta Fm, Neuquén Basin, Argentina): evidence for overpressure and horizontal compression. Journal of the Geological Society, London, 166 (4), 695-709, doi 10.1144/0016-76492008-111.

Rodriguez, F., Villar, J. H., Baudino, R., 2007. Hydrocarbon generation, migration, and accumulation related to igneous intrusions: An atypical petroleum system from the Neuquén Basin of Argentina. SPE Paper 107926-PP, 4 p.

Rodriguez Monreal, F., Villar, H.J., Baudino, R., Delpino, D., Zencich, S., 2009. Modeling an atypical petroleum system: A case study of hydrocarbon generation, migration and accumulation related to igneous intrusions in the Neuquen Basin, Argentina. Marine and Petroleum Geology, 26, 590-605. 
Ruffet, G., Féraud, G., Amouric, M., 1991. Comparison of ${ }^{40} \mathrm{Ar} /{ }^{39} \mathrm{Ar}$ conventional and laser dating of biotites fram the North Trégor Batholith. Geochimica et Cosmochimica Acta $55,1675-1688$.

Ruffet, G., Féraud, G., Ballèvre, M., Kiénast, J-R., 1995. Plateau ages and excess argon in phengites: an ${ }^{40} \mathrm{Ar}-{ }^{39} \mathrm{Ar}$ laser probe study of Alpine micas (Sesia Zone, Western Alps, northern Italy). Chemical Geology (Isotopic Geosciences Section), 121, 327-343.

Salas, J., 1892. Noticias y documentos sobre el carbón de piedra de San Rafael (Mendoza). Revista del Museo de La Plata, 4, 138.

Silvestro, J., Kraemer, P., 2005. Evolución tecto-sedimentaria de la Cordillera Principal en el sector surmendocino a los $35^{\circ} 30^{\prime} \mathrm{S}$, Faja plegada de Malargüe, Republica Argentina. $6^{\circ}$ Congreso de Exploración y Desarrollo de Hidrocarburos, Artículo 25, Mar del Plata, CDROM.

Silvestro, J., Kraemer, P., Achilli, F., Brinkworth, W., 2005. Evolución de las cuencas sinorogénicas de la Cordillera Principal entre $35^{\circ}-36^{\circ} \mathrm{S}$, Malargüe. Revista de la Asociación Geológica Argentina, 60 (4), 627-643.

Stoneley, R., 1983. Fibrous calcite veins, overpressures, and primary oil migration. American Association of Petroleum Geologists Bulletin, 67, 1427-1428.

Swarbrick, R.E., Osborne, M.J., Yardley G.S., 2002. Comparison of overpressure magnitude resulting from the main generating mechanisms. In: Huffman, A.R., Bowers, G.L. (Eds.), Pressure regimes in sedimentary Basins and their Prediction. American Association of Petroleum Geologists Memoir 76, 1-12.

Urien, C.M., Zambrano, J.J., 1994. Petroleum systems in the Neuquén Basin, Argentina. In: Magoon, L.B. \& Dow, W.G. (eds) The Petroleum System — from Source to Trap. American Association of Petroleum Geologists Memoir, 60, 513-534.

Vergani, G.D., Tankard, A.J., Belotti, H.J., Welsink, H.J., 1995. Tectonic evolution and paleogeography of the Neuquén Basin, Argentina. In: Tankard, A.J., Suárez S., R., Welsink, H.J. (eds), Petroleum Basins of South America. American Association of Petroleum Geologists Memoir, 62, 383-402.

Videla Leaniz, J.R., 1945. Informe mensual sobre los trabajos efectuados en abril 1945 (Comisión Carbón Mineral n 55). Yacimientos Carboníferos Fiscales (unpublished report).

Villar, H.J., Legarreta, L., Cruz, C.E., Laffitte, G., Vergani, G., 2006. Los cinco sistemas petroleros coexistentes en el sector sudeste de la Cuenca Neuquina: definición geoquímica y comparación a lo largo de una transecta de $150 \mathrm{~km}$. Boletín de 
Informaciones Petroleras, Cuarta época, 3, 50-66.

Witte, J., Bonora, M., Carbone, C., Oncken, O., 2012. Fracture evolution in oil-producing sills of the Rio Grande Valley, northern Neuquén Basin, Argentina. American Association of Petroleum Geologists Bulletin, 96 (7), 1253-1277.

Zanella, A., Cobbold, P. R., Le Carlier de Veslud, C., 2014. Physical modelling of chemical compaction, overpressure development, hydraulic fracturing and thrust detachments in organic-rich source rock. Marine and Petroleum Geology, 55, 262-274.

\section{Figure captions}

Fig. 1. Geological map of the northern Neuquén Basin, Mendoza Province. Data are from the following geological maps: Volcan Maipo, Malargüe and Barrancas (SEGEMAR). Stars refer to bitumen mines visited in this study $(1=$ Mercedes; $2=$ Minacar; $3=$ Aida; $4=\mathrm{La}$ Malarguiña; 5 = La Valenciana; $6=$ El Toki; 7 = Mallín Largo; $8=$ Los Castaños; $9=$ Santa Rosa; 10 = General Mitré; 11 = Eloise; 12 = Loncoché). The Mendoza Group (Early Cretaceous) includes source rock of the Vaca Muerta Fm.

Fig. 2. Generalized stratigraphic column of the northern Neuquén Basin (modified, after Witte et al. 2012). $\mathrm{Pli}=$ Pliocene Mio $=$ Miocene $; \mathrm{Oli}=$ Oligocene $;$ Eoc $=$ Eocene $; \mathrm{Pal}=$ Palaeogene Maa = Maastrichtian $; \mathrm{Cp}=$ Campanian San = Santonian Con = Coniacian $;$ Tur $=$ Turonian Cen $=$ Cenomanian; $\mathrm{Alb}=$ Albian; $\mathrm{Apt}=$ Aptian $; \mathrm{Brm}=$ Barremian $; \mathrm{Hau}=$ Hauterivian; Vlg = Valanginian $;$ Ber $=$ Berriasian; Tith $=$ Tithonian; Kim $=$ Kimmeridgian; Oxf $=$ Oxfordian; Sin-Clv $=$ Sinemurian to Callovian; Het $=$ Hettangian .

Fig. 3. Regional E-W section of the southern Malargüe fold and thrust belt (modified, after Giambiagi et al. 2009; Silvestro \& Kraemer 2005; Witte et al. 2012). For location, see Fig. 1.

Fig. 4. Aromaticity $(\mathrm{Fa})$ as a function of atomic ratio $(\mathrm{H} / \mathrm{C})$, for bitumen from various localities of the northern Neuquén basin, relative to standard bitumen subtypes (see Jacob, 1989).

Fig. 5. A. Schematic E-W section of Cerro Mallín de la Leona, including bitumen veins of Mercedes Mine (modified, after Biondi 1942a). The main bitumen vein is a sill parallel to the 
bedding in an anticlinal structure. The thickness of the bitumen is variable and is greater in the hinge of the anticline. B. Loose fragment of bitumen near entrance to main gallery of Mercedes Mine. C. Remains of entrance to main gallery, Mercedes Mine.

Fig. 6. A. General view of Minacar (or General San Martín) Mine. B. Recent quarry, showing two bitumen veins. Vein at left cuts across strata, whereas sill at right has intruded parallel to bedding. C. Close-up view of bitumen sill, which has pencillate structure. D. Main igneous intrusive body (andesite), Minacar area. Body has metamorphic aureole.

Fig. 7. A. Pencillate bitumen vein, from near gallery entrance, Los Castaños Mine. Edges of vein (horizontal) are parallel to bedding in Vaca Muerta shale, whereas 'fibres' of bitumen are perpendicular to it. B. Beef veins within Vaca Muerta shale near Los Castaños Mine. Veins are strictly parallel to bedding and contain hydrocarbons. C. Outcropping bitumen vein, Mallín Largo Mine. Bitumen crosscuts and impregnates Mendoza Group. D. Outcropping bitumen vein, El Toki Mine. Vein is parallel to bedding in Early Tertiary conglomerate.

Fig. 8. A. Outcropping bitumen veins within overturned strata, Eloisa Mine (view S). Veins strike about $075^{\circ}$ and crosscut sandstones of Neuquén Group (Late Cretaceous), just beneath gypsum of Huitrín Fm (Mid-Cretaceous). B. Bitumen vein, General Mitre Mine. Vein crosscuts strata of Neuquén Group (Late Cretaceous).

Fig. 9. Results for ${ }^{39} \mathrm{Ar}-{ }^{40} \mathrm{Ar}$ dating. ${ }^{39} \mathrm{Ar}-{ }^{40} \mathrm{Ar}$ spectra are for 20 samples of volcanic rocks. For analytical procedure, see Ruffet et al. (1991, 1995). Irradiation standard was sanidine TCR-2 (28.608 \pm 0.033 Ma according to Renne et al., 1998, 2010 and 2011)). For each step, error bars are at $1 \sigma$ level. For location of samples, see Table 2.

Fig. 10. La Valenciana Mine. Oblique 3D view shows geological map (in colour), on a background of topographic relief (grey tones). Cutting across sedimentary sequence (blue for Vaca Muerta Fm) are main bitumen sill (black) and multiple intrusive bodies of igneous rocks, including dykes and sills of andesite (red) or dacite (orange). Dykes appear to radiate southeastwards from Cerro Puchenque volcanic edifice. For location, see Fig. 1.

Fig. 11. A. Vein of calcite beef within Vaca Muerta Fm, La Valenciana syncline. B. Calcite beef near andesitic sill ( $60 \mathrm{~cm}$ beneath intrusion). Beef appears to be more coarsely 
crystalline. C. Patch of travertine near an andesitic dyke (at $40 \mathrm{~cm}$ from intrusion). D. Thin section of beef from La Valenciana. Calcite fibres curve at edges of veins. Nearby are patches of bitumen, between calcite fibres, suggesting a synchronous development for both calcite fibres and bitumen. Red box corresponds to the figure below. E. Image of bitumen (left). Composite BSE and X-ray image shows composition of a part of beef vein (right). Intensities of colours reveal concentrations of elements (carbon, aluminium, silica, calcium).

Fig. 12. A. Westerly panoramic view ( $\mathrm{N}$ to $\mathrm{S}$ ), La Valenciana syncline. White outcrops in foreground are of evaporites (Auquilco Fm). Mountain in background (Cerro Puchenque) is an andesitic pluton. B. Remains of La Valenciana Mine (view along strike to W). Dark mounds are mine dumps of bitumen and shale, close to old mine galleries. C. One of main vertical andesitic dykes, cutting approximately E-W through Vaca Muerta Fm. D. Dacite from northern La Valenciana syncline.

Fig. 13. Results of ${ }^{39} \mathrm{Ar}-{ }^{40} \mathrm{Ar}$ dating, La Valenciana area. Spectra are for 19 samples of volcanic rocks. For analytical procedure, see Ruffet et al. (1991, 1995). Irradiation standard was sanidine TCR-2 (28.608 \pm 0.033 Ma according to Renne et al., 1998, 2010 and 2011)). For each step, error bars are at $1 \sigma$ level.

Fig. 14 : Weighted frequency diagrams of [A] apparent ages, plateau ages (PA) and pseudoplateau ages (PPA) of the whole set of ${ }^{39} \mathrm{Ar}-{ }^{40} \mathrm{Ar}$ data from this study and [B] apparent ages for andesite and dacite samples from La Valenciana syncline.

Table 1. Bitumen mines of the Malargüe fold-and-thrust belt that we were able to visit. For location on regional map, see Figure 1.

Table $2 .{ }^{39} \mathrm{Ar}-{ }^{40} \mathrm{Ar}$ ages of volcanic rocks in the Malargüe fold and thrust belt area. 
ACCEPTED MANUSCRIPT

\begin{tabular}{|r|l|c|c|c|c|}
\hline \multirow{2}{*}{$n^{\circ}-$} & \multirow{3}{*}{ Name } & \multicolumn{3}{|c|}{ Coordinates } & Host rock \\
\cline { 3 - 6 } & & Latitude S & Longitude W & Elevation (m) & \\
\hline 1 & Mercedes & $36^{\circ} 4^{\prime} 30^{\prime \prime}$ & $70^{\circ} 1^{\prime} 19^{\prime \prime}$ & 2024 & Vaca Muerta \\
\hline 2 & Minacar & $35^{\circ} 51^{\prime} 58^{\prime \prime}$ & $70^{\circ} 4^{\prime} 5^{\prime \prime}$ & 2138 & Vaca Muerta \\
\hline 3 & Aida & $35^{\circ} 54^{\prime} 36^{\prime \prime}$ & $69^{\circ} 48^{\prime} 30^{\prime \prime}$ & 1648 & Mendoza Group \\
\hline 4 & La Malarguiña & $35^{\circ} 35^{\prime} 18^{\prime \prime}$ & $69^{\circ} 56^{\prime} 06^{\prime \prime}$ & 2146 & Vaca Muerta \\
\hline 5 & La Valenciana & $35^{\circ} 33^{\prime} 2^{\prime \prime}$ & $69^{\circ} 54^{\prime} 11^{\prime \prime}$ & 2000 & Vaca Muerta \\
\hline 6 & El Toki & $35^{\circ} 27^{\prime} 11^{\prime \prime}$ & $69^{\circ} 46^{\prime} 51^{\prime \prime}$ & 1736 & Malargúe Group \\
\hline 7 & Mallín Largo & $35^{\circ} 14^{\prime} 4^{\prime \prime}$ & $69^{\circ} 45^{\prime} 23^{\prime \prime}$ & 1850 & Vaca Muerta \\
\hline 8 & Los Castaños & $35^{\circ} 13^{\prime} 54^{\prime \prime}$ & $69^{\circ} 47^{\prime} 19^{\prime \prime}$ & 2137 & Vaca Muerta \\
\hline 9 & Santa Rosa & $35^{\circ} 7^{\prime} 38^{\prime \prime}$ & $69^{\circ} 59^{\prime} 20^{\prime \prime}$ & 2740 & Vaca Muerta \\
\hline 10 & General Mitré & $34^{\circ} 45^{\prime} 2^{\prime \prime}$ & $69^{\circ} 40^{\prime} 6^{\prime \prime}$ & 2552 & Neuquén Group \\
\hline 11 & Eloisa & $34^{\circ} 41^{\prime} 21^{\prime \prime}$ & $69^{\circ} 42^{\prime} 37^{\prime \prime}$ & 3242 & Vaca Muerta \\
\hline 12 & Loncoché & $35^{\circ} 35^{\circ} 56^{\prime \prime}$ & $69^{\circ} 37^{\prime} 29^{\prime \prime}$ & 1629 & Vaca Muerta \\
\hline
\end{tabular}




\begin{tabular}{|c|c|c|c|c|c|}
\hline Site & Sample & Latitude (S) & Longitude (W) & Áges (Ma) & Type or mineral \\
\hline Aida & 11-AIDA-1 & $\begin{array}{c}35^{\circ} 54^{\prime} 33.2^{\prime \prime} \\
-\end{array}$ & $\begin{array}{c}69^{\prime} 48^{\prime} 24.5^{\prime \prime} \\
-\end{array}$ & $\begin{array}{l}12.5 \pm 0.10 \\
14.2 \pm 0.10\end{array}$ & $\begin{array}{l}\text { Whole rock (a) } \\
\text { Amphibole (a) }\end{array}$ \\
\hline Minacar & $\begin{array}{l}\text { 11-MINACA-1 } \\
\text { 11-MINACA-2 } \\
\text { 11-MINACA-3 } \\
\text { 11-MINACA-4 } \\
\text { 11-MINACA-5 } \\
\text { 11-MINACA-6 }\end{array}$ & $\begin{array}{l}35^{\circ} 51^{\prime} 54.9^{\prime \prime} \\
35^{\circ} 51^{\prime} 55.7^{\prime \prime} \\
35^{\circ} 50^{\prime} 35.3^{\prime \prime} \\
35^{\circ} 46^{\prime} 25.9^{\prime \prime} \\
35^{\circ} 45^{\prime} 21.1^{\prime \prime} \\
-\end{array}$ & $\begin{array}{c}70^{\circ} 04^{\prime} 10.8^{\prime \prime} \\
70^{\circ} 04^{\prime} 03.2^{\prime \prime} \\
70^{\circ} 02^{\prime} 41.7^{\prime \prime} \\
70^{\circ} 06^{\prime} 30.3^{\prime \prime} \\
70^{\circ} 06^{\prime} 39.7^{\prime \prime} \\
-\end{array}$ & $\begin{array}{l}13 \pm 0.29 \\
14.7 \pm 0.18 \\
13.67 \pm 0.08 \\
0.228 \pm 0.12 \\
0.301 \pm 0.022 \\
0.722 \pm 0.028 \\
0.751 \pm 0.06\end{array}$ & $\begin{array}{l}\text { Whole rock (a) } \\
\text { Whole rock (a) } \\
\text { Amphibole (a) } \\
\text { Whole rock (i) } \\
\text { Whole rock (i) } \\
\text { Whole rock (i) } \\
\text { Biotite (i) }\end{array}$ \\
\hline El Toki & \begin{tabular}{|l|} 
TOKI-1 \\
TOKI-3 \\
TOKI-4 \\
TOKI-5 \\
TOKI-6
\end{tabular} & $\begin{array}{l}35^{\circ} 26^{\prime} 48.4^{\prime \prime} \\
35^{\circ} 26^{\prime} 48.0^{\prime \prime} \\
35^{\circ} 27^{\prime} 05.2^{\prime \prime} \\
35^{\circ} 27^{\prime} 03.6^{\prime \prime} \\
35^{\circ} 27^{\prime} 03.6^{\prime \prime}\end{array}$ & $\begin{array}{l}69^{\circ} 46^{\prime} 47.9^{\prime \prime} \\
69^{\circ} 46^{\prime} 55.8^{\prime \prime} \\
69^{\circ} 46^{\prime} 43.9^{\prime \prime} \\
69^{\circ} 47^{\prime} 17.4^{\prime \prime} \\
69^{\circ} 47^{\prime} 17.4^{\prime \prime}\end{array}$ & $\begin{array}{l}12.91 \pm 0.09 \\
10.64 \pm 0.05 \\
12.01 \pm 0.11 \\
10.3 \pm 0.05 \\
13.13 \pm 0.12\end{array}$ & $\begin{array}{l}\text { Whole rock (a) } \\
\text { Whole rock (a) } \\
\text { Whole rock (a) } \\
\text { Whole rock (a) } \\
\text { Whole rock (a) }\end{array}$ \\
\hline La Valenciana & $\begin{array}{l}\text { PLOMO-1 } \\
\text { M11-003A } \\
\text { M11-003B } \\
\text { 11-VA-1 } \\
\text { 11-VA-2 } \\
\text { 11-VA-3 } \\
\text { M12-028 } \\
\text { M12-029 } \\
\text { M12-038 } \\
\text { M12-039 } \\
\text { M12-042 } \\
\text { M12-043 } \\
\text { M12-046 } \\
\text { M12-052 }\end{array}$ & $\begin{array}{c}35^{\circ} 30^{\prime} 33.3^{\prime \prime} \\
35^{\circ} 33^{\prime} 09.8^{\prime \prime} \\
35^{\circ} 33^{\prime} 09.8^{\prime \prime} \\
35^{\circ} 33^{\prime} 02.2^{\prime \prime} \\
- \\
35^{\circ} 32^{\prime} 55.1^{\prime \prime} \\
35^{\circ} 32^{\prime} 36.9^{\prime \prime} \\
35^{\circ} 31^{\prime} 40.8^{\prime \prime} \\
- \\
35^{\circ} 31^{\prime} 40.8^{\prime \prime} \\
35^{\circ} 31^{\prime} 50.9^{\prime \prime} \\
35^{\circ} 31^{\prime} 30.5^{\prime \prime} \\
- \\
35^{\circ} 31^{\prime} 07.2^{\prime \prime} \\
35^{\circ} 31^{\prime} 16.6^{\prime \prime} \\
35^{\circ} 31^{\prime} 43.5^{\prime \prime} \\
- \\
35^{\circ} 31^{\prime} 50.5^{\prime \prime} \\
-\end{array}$ & $\begin{array}{c}69^{\circ} 55^{\prime} 47.4^{\prime \prime} \\
69^{\circ} 54^{\prime} 20.7^{\prime \prime} \\
69^{\circ} 54^{\prime} 20.7^{\prime \prime} \\
69^{\circ} 54^{\prime} 24.3^{\prime \prime} \\
- \\
69^{\circ} 54^{\prime} 06.6^{\prime \prime} \\
69^{\circ} 53^{\prime} 54.4^{\prime \prime} \\
69^{\circ} 55^{\prime} 37.0^{\prime \prime} \\
- \\
69^{\circ} 55^{\prime} 37.0^{\prime \prime} \\
69^{\circ} 53^{\prime} 52.3^{\prime \prime} \\
69^{\circ} 54^{\prime} 17.8^{\prime \prime} \\
- \\
69^{\circ} 54^{\prime} 32.6^{\circ} 54^{\prime} 44.9^{\prime \prime} \\
69^{\circ} 53^{\prime} 47.3^{\prime \prime} \\
- \\
69^{\circ} 55^{\prime} 07.7^{\prime \prime} \\
-\end{array}$ & $\begin{array}{l}9.87 \pm 0.05 \\
0.165 \pm 0.03 \\
0.177 \pm 0.02 \\
10.21 \pm 0.14 \\
9.99 \pm 0.20 \\
14.63 \pm 0.13 \\
12.88 \pm 0.36 \\
12.63 \pm 0.43 \\
11.39 \pm 0.36 \\
10.74 \pm 0.11 \\
10.84 \pm 0.20 \\
9.44 \pm 0.04 \\
9.64 \pm 0.45 \\
9.92 \pm 0.10 \\
10.77 \pm 0.36 \\
10.92 \pm 0.28 \\
9.56 \pm 0.33 \\
10.65 \pm 0.35 \\
9.67 \pm 0.17\end{array}$ & $\begin{array}{l}\text { Whole rock (a) } \\
\text { Whole rock (i) } \\
\text { Whole rock (i) } \\
\text { Whole rock (a) } \\
\text { Amphibole (a) } \\
\text { Whole rock (a) } \\
\text { Whole rock (a) } \\
\text { Whole rock (a) } \\
\text { Amphibole (a) } \\
\text { Whole rock (a) } \\
\text { Whole rock (a) } \\
\text { Whole rock (d) } \\
\text { Sanidine (d) } \\
\text { Whole rock (d) } \\
\text { Whole rock (a) } \\
\text { Whole rock (a) } \\
\text { Amphibole (a) } \\
\text { Whole rock (a) } \\
\text { Amphibole (a) }\end{array}$ \\
\hline Malarguina & \begin{tabular}{|l|} 
M11-019 \\
M12-030
\end{tabular} & $\begin{array}{l}35^{\circ} 34^{\prime} 18.3^{\prime \prime} \\
35^{\circ} 35^{\prime} 20.3^{\prime \prime}\end{array}$ & $\begin{array}{l}69^{\circ} 55^{\prime} 16.5^{\prime \prime} \\
69^{\circ} 56^{\prime} 01.3^{\prime \prime}\end{array}$ & $\begin{array}{l}0.195 \pm 0.01 \\
0.216 \pm 0.01\end{array}$ & $\begin{array}{l}\text { Whole rock (i) } \\
\text { Whole rock (i) }\end{array}$ \\
\hline Eloisa & M12-018 & $34^{\circ} 41^{\prime} 18.9^{\prime \prime}$ & $69^{\circ} 42^{\prime} 38.8^{\prime \prime}$ & $3.61 \pm 0.050$ & Whole rock (a) \\
\hline Rio Diamante & M12-023 & $\begin{array}{c}34^{\circ} 40^{\prime} 51.6^{\prime \prime} \\
-\end{array}$ & $\begin{array}{c}69^{\circ} 34^{\prime} 10.4^{\prime \prime} \\
-\end{array}$ & $\begin{array}{l}6.09 \pm 0.03 \\
6.24 \pm 0.16\end{array}$ & $\begin{array}{l}\text { Whole rock (a) } \\
\text { Amphibole (a) }\end{array}$ \\
\hline
\end{tabular}




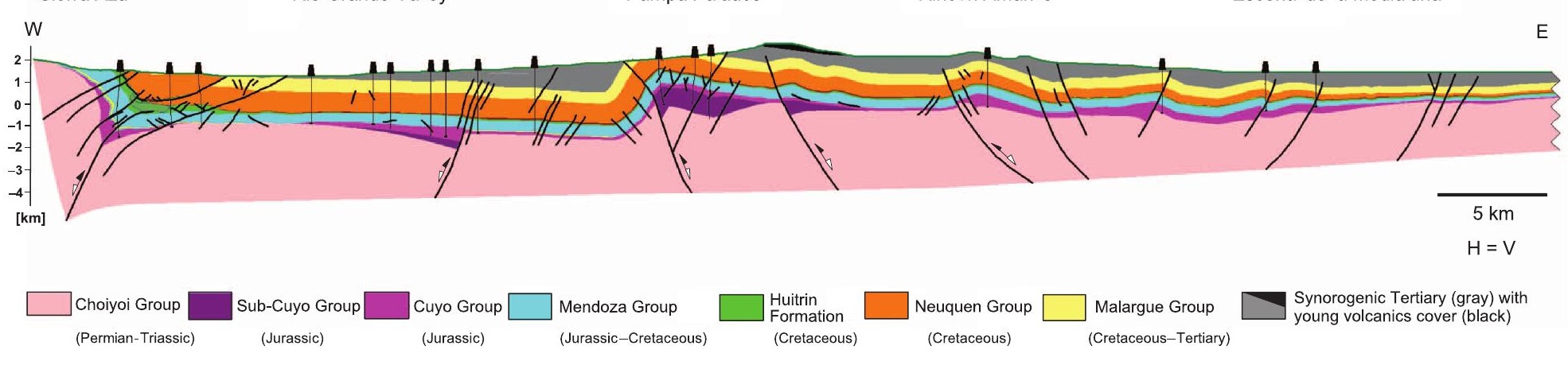




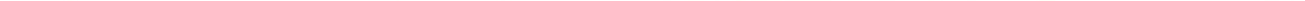




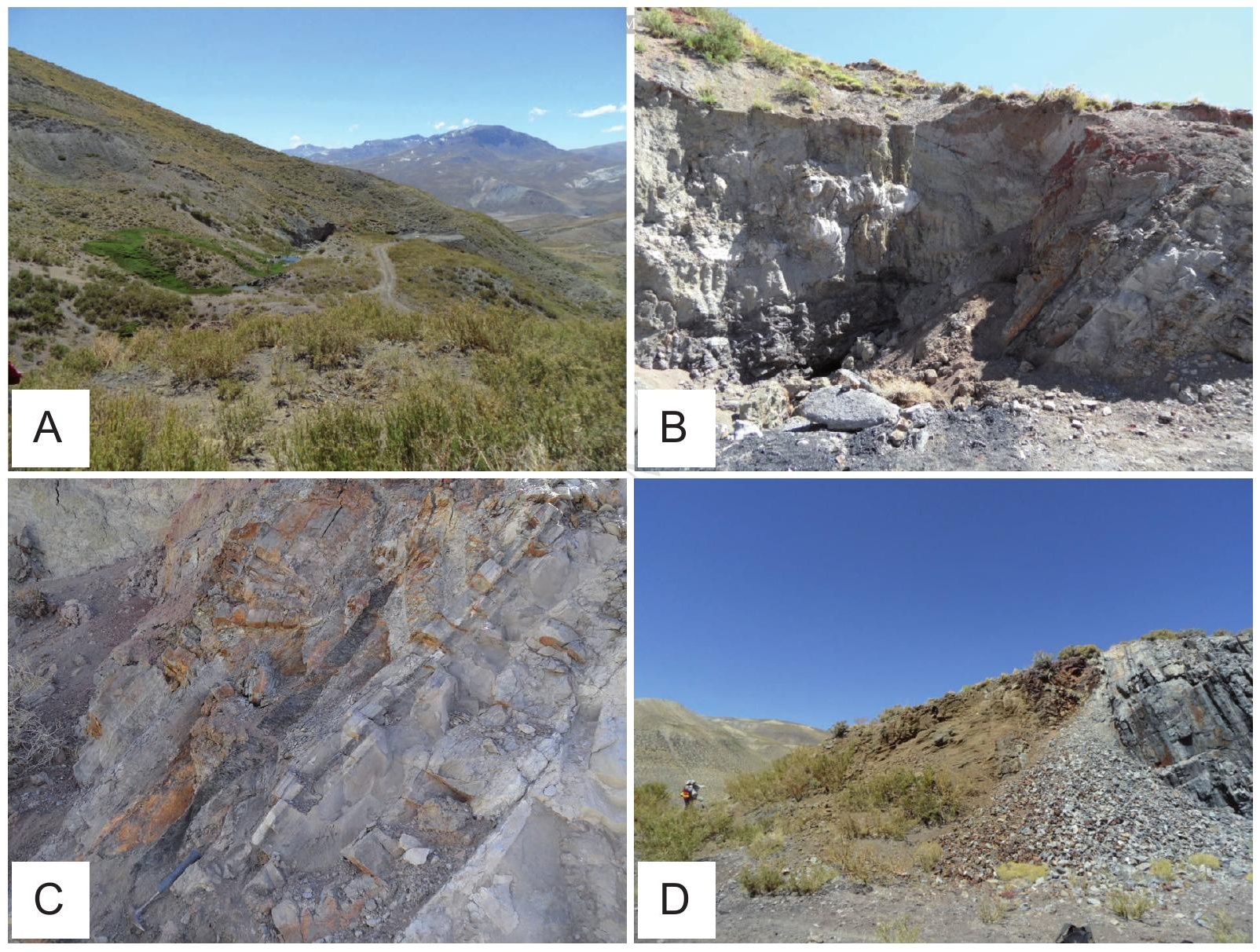




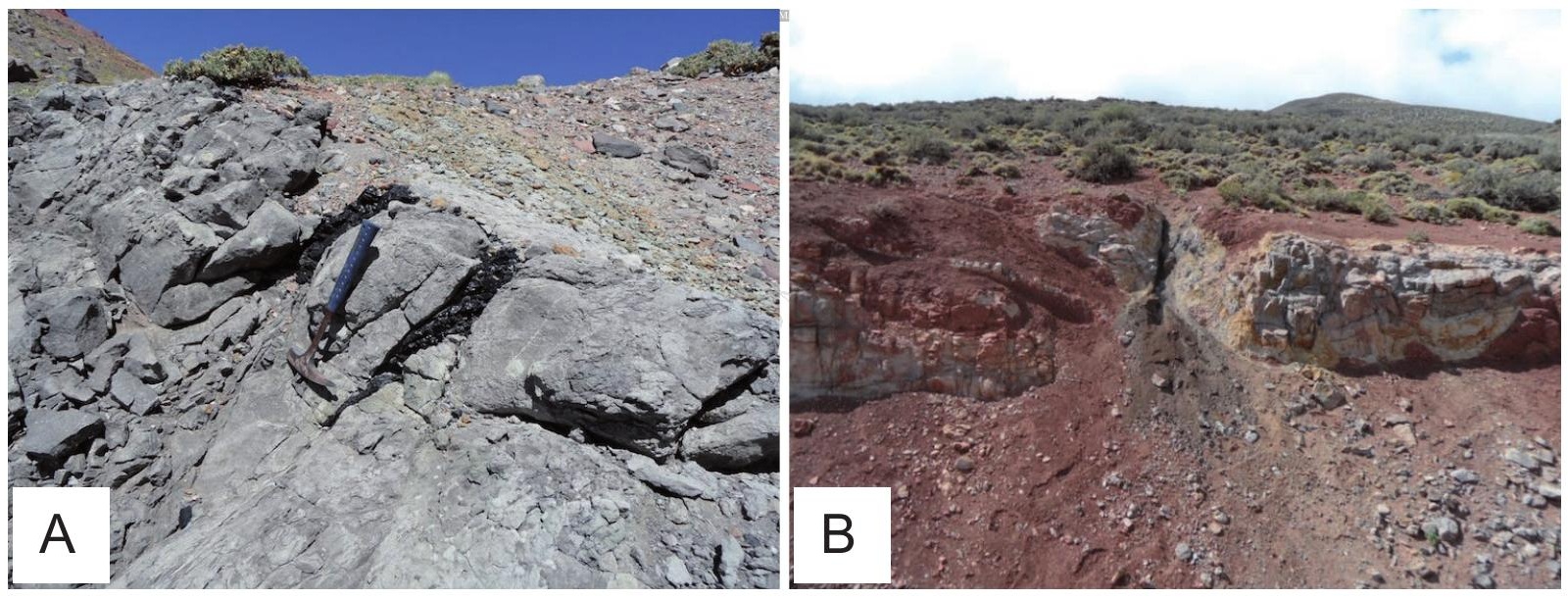




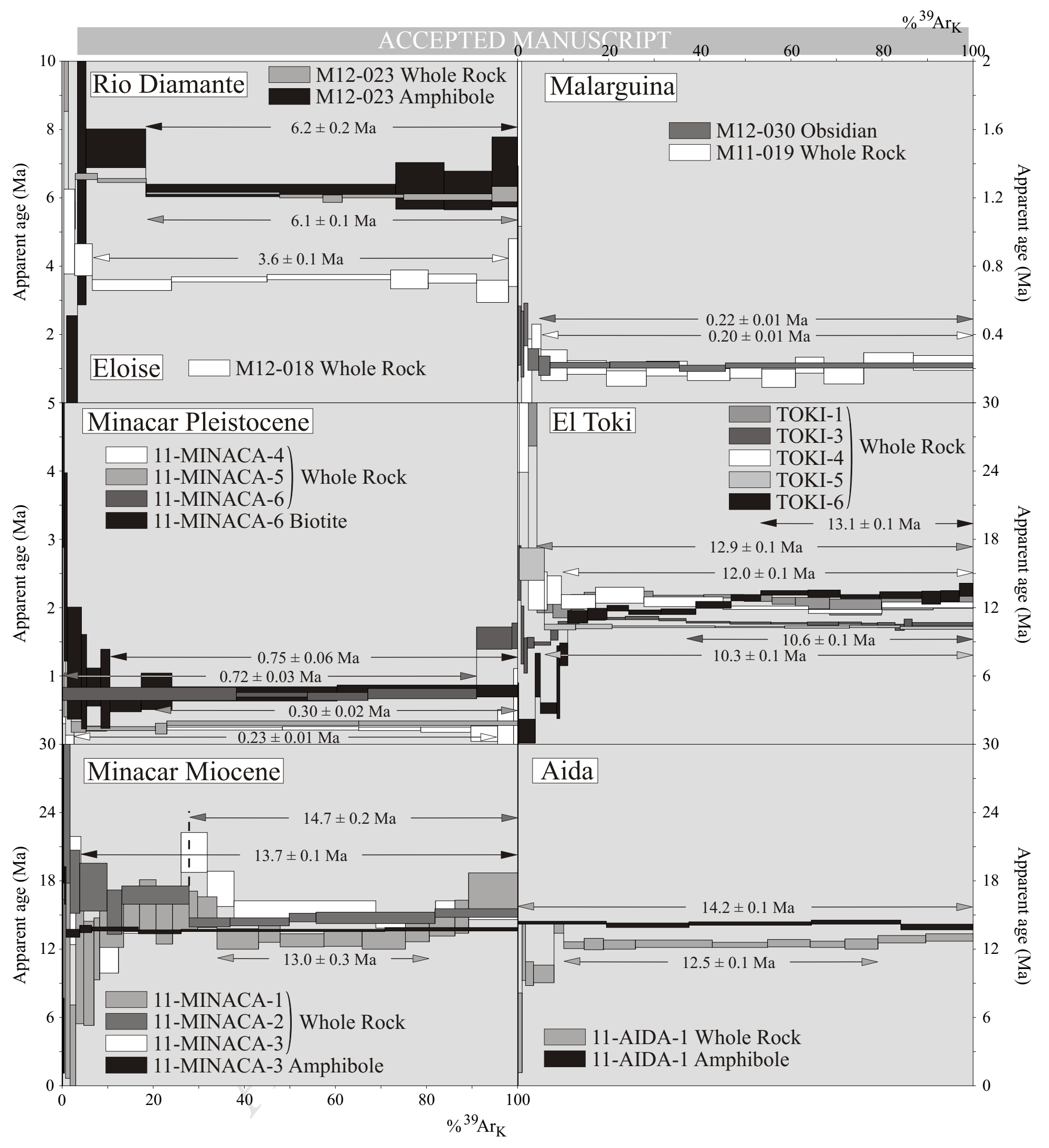




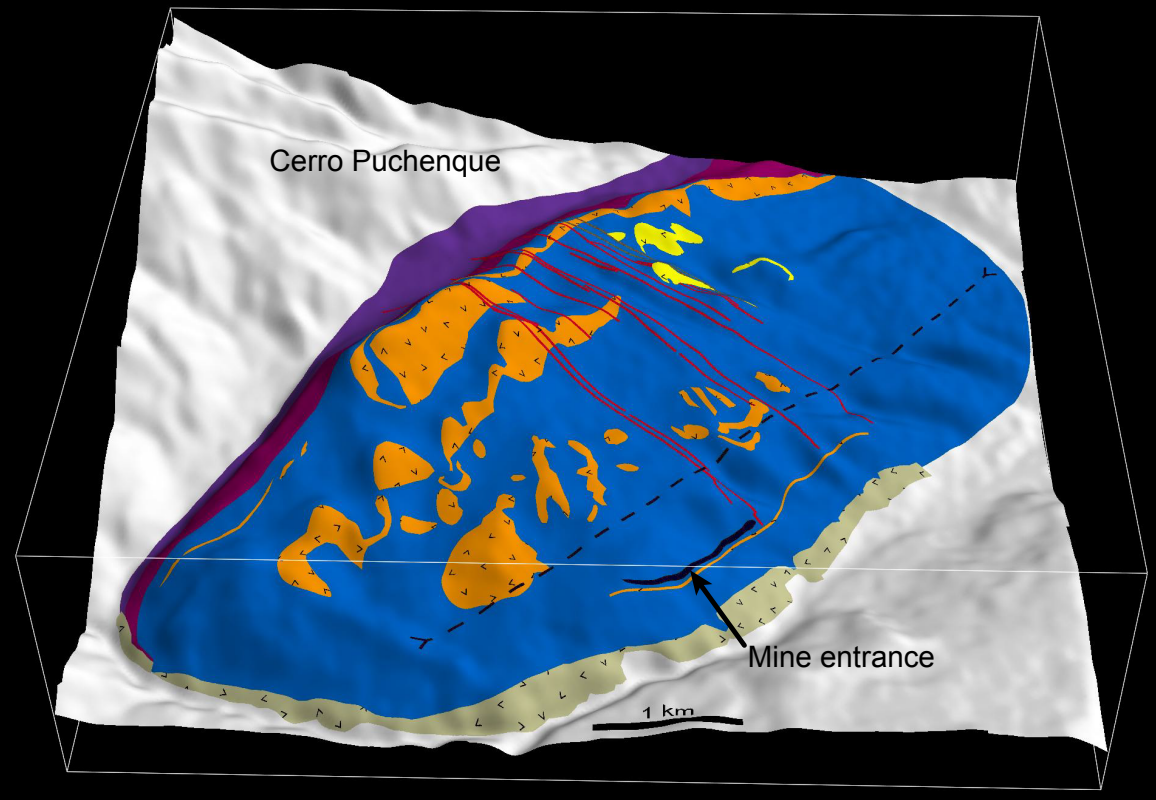

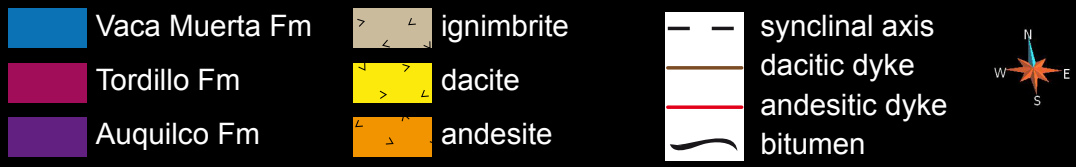




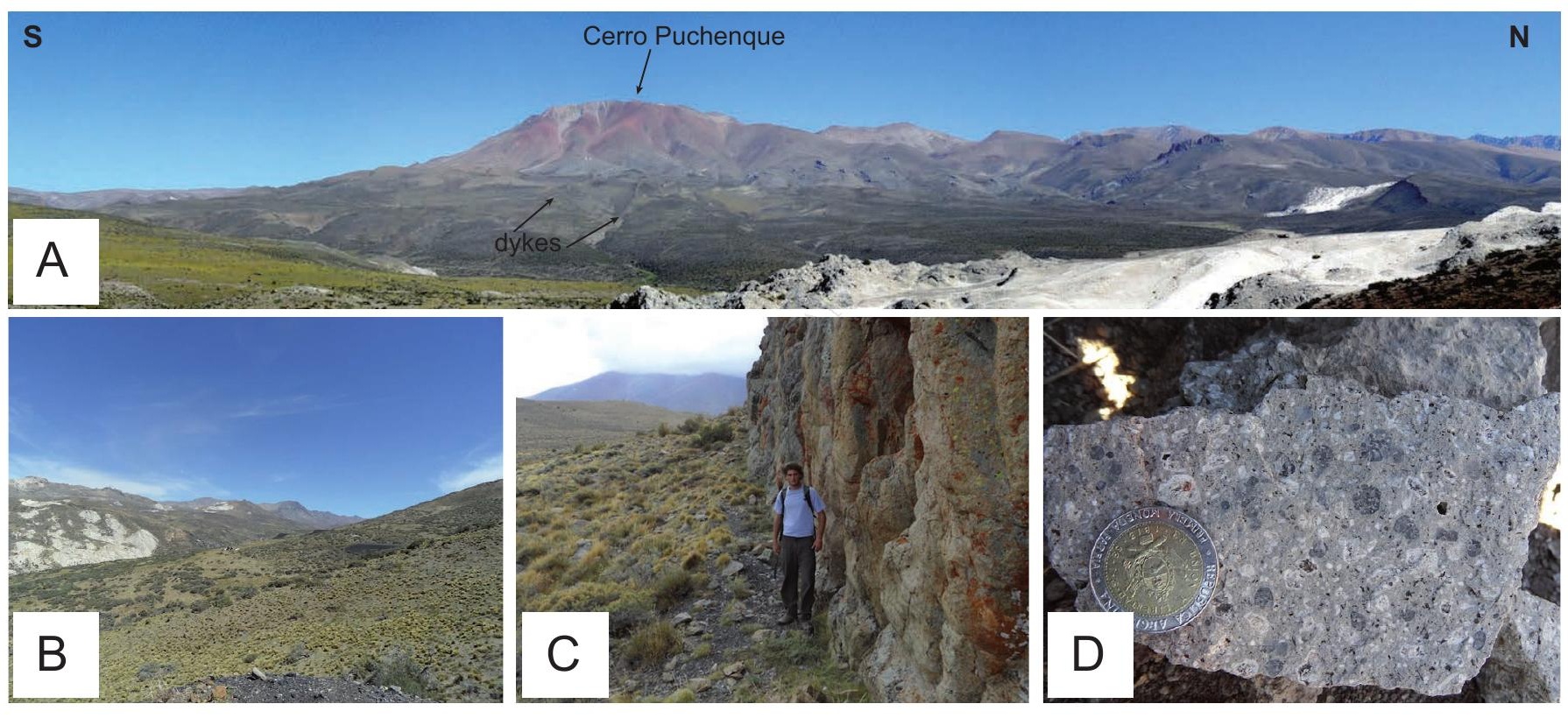




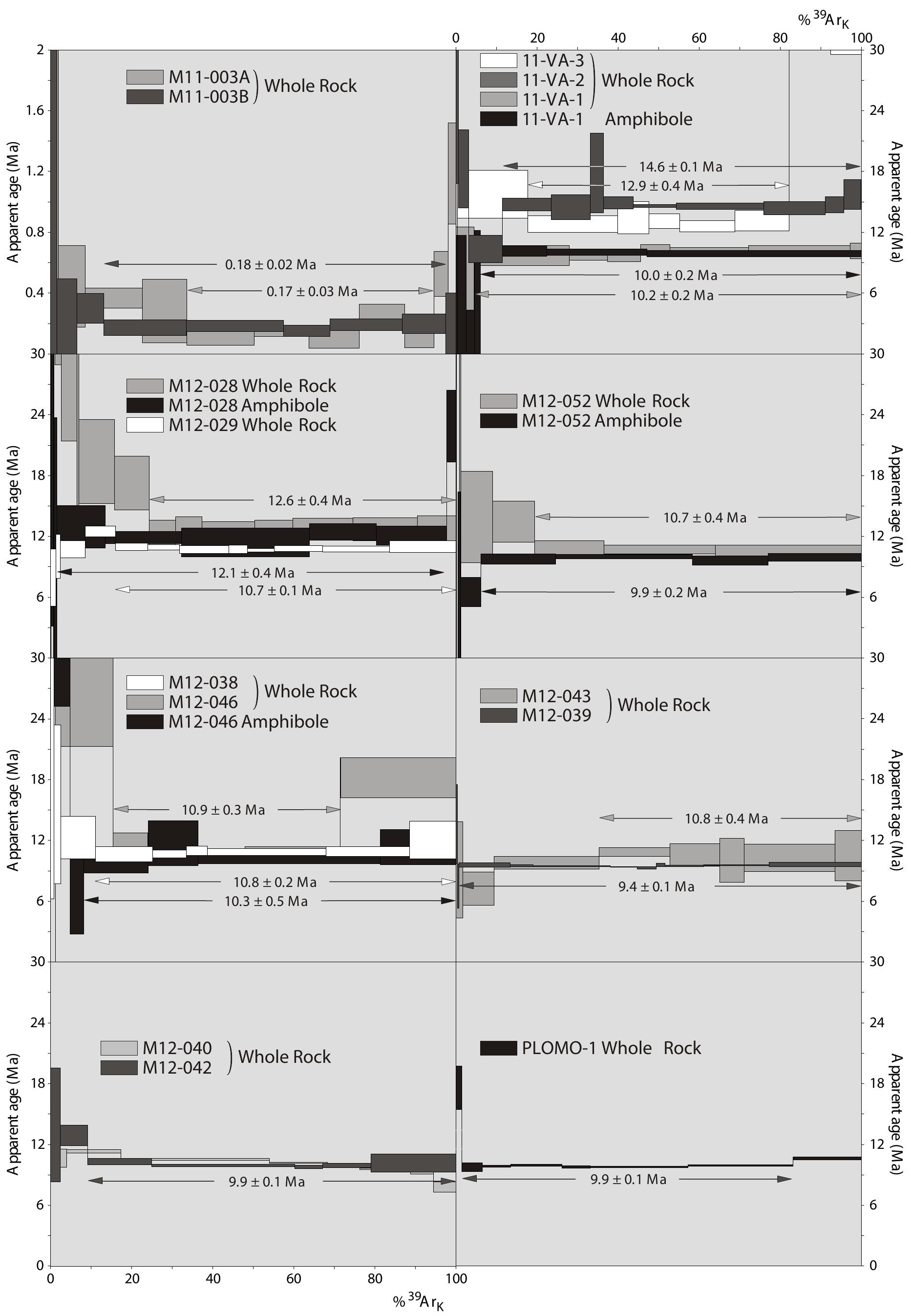



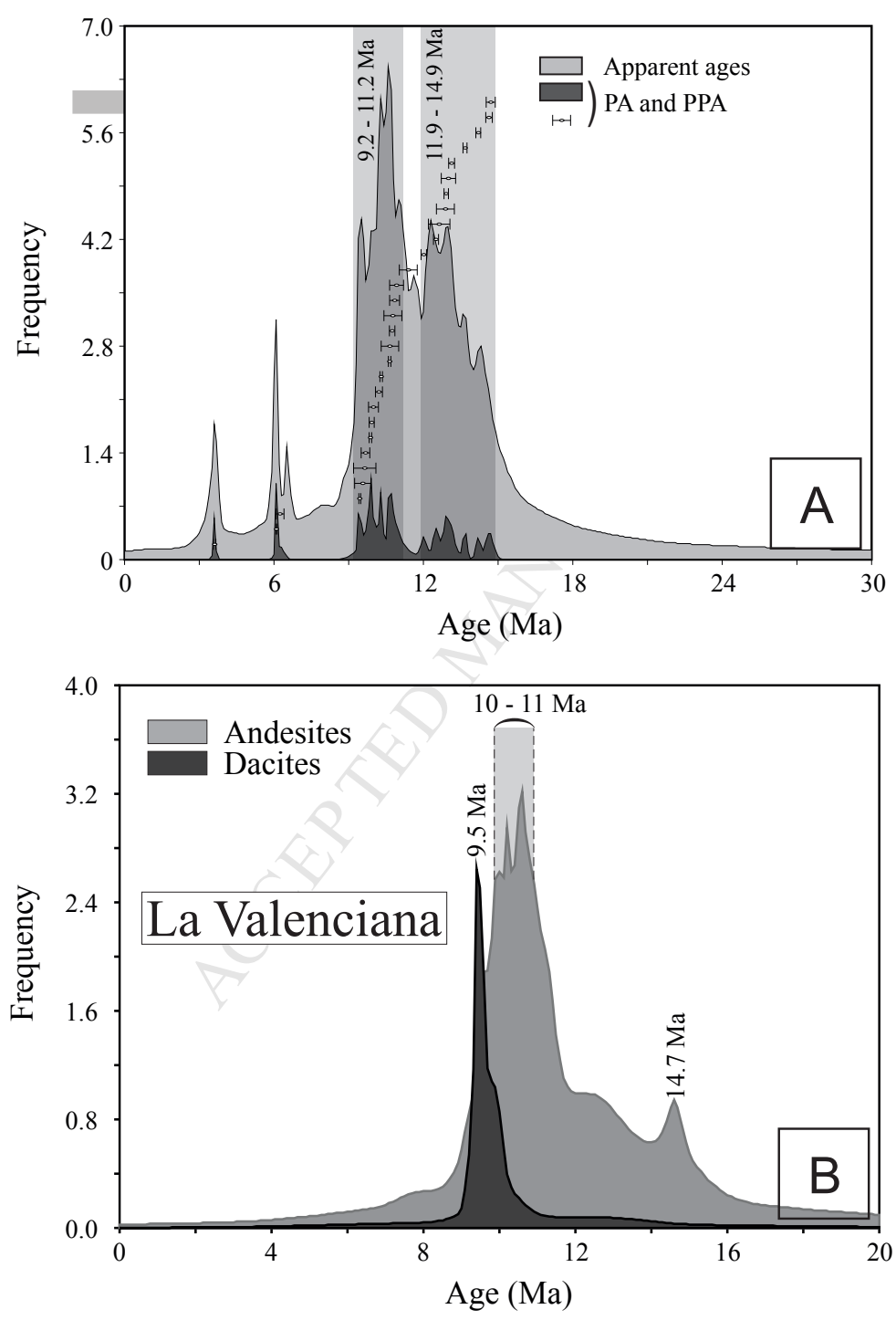


\section{Highlights}

1. Beef and bitumen veins are widespread in the northern part of the Neuquén Basin.

2. Beef and bitumen veins provide geological evidence for hydraulic fracturing.

3. Hydrocarbon generation led to fluid overpressure and hydraulic fracturing.

4. Volcanic activity has contributed to maturation of the source rock. 